\title{
Migration Crisis and Its Impact on the Internal Situation in Turkey
}

\begin{abstract}
The aim of this article is to discuss the impact of the migration crisis on the social situation in Turkey. The article consists of three parts. In the first part, the author discusses the role of Turkey in overcoming the migration crisis along with statistics concerning the number of refugees in this country. The second part presents the state's policy towards Syrian refugees and its evolution. The third part includes an analysis of the consequences which the migration crisis and the influx of refugees has caused in the socio-political situation of Turkey. This part also contains an analysis of public opinion surveys on the attitude of Turks towards the refugee community.
\end{abstract}

Keywords: Migration Crisis, Turkey, Refugees, Syria

\section{Introduction}

The issue of migration, regardless of the reasons, is one of the main challenges of the contemporary world. Migrations affect almost all spheres of social and economic life. Foreigners are usually seen as a contrast to the citizens of a nation-state and a challenge to the integrity of the local community. The host population may treat them as a factor which interferes with economic, cultural or political stability. Analyzes on migration show that, among others, local communities perceive migrants as people who distort the labor market, cause lowering of wages and affect the unemployment rates of the local community. ${ }^{1}$ The influx of

\footnotetext{
^ Dominika Liszkowska - Koszalin University of Technology, e-mail: dominika_liszkowska@wp.pl, ORCID: 0000-0001-6312-341X.

${ }^{1}$ A. Llanos-Antczak, Problemy społeczno-ekonomiczne jako jedne z najgroźniejszych wyzwań dla bezpieczeństwa europejskiego w XXI wieku (Socio-Economic Problems as One
} 
immigrants also causes dissatisfaction with the host community, primarily due to their predispositions to commit crimes, assimilation problems and being perceived as a threat to national identity.

The view according to which migrants can be perceived as a security threat has been continuously present for many years. According to Philippe Bourbeau, issues which have become particularly disturbing include: (1) considering the concept of migration in a collective sense, and thus determining its impact on creating an existential threat to the security of the state and society; (2) recognizing the phenomenon of immigration as threatening to state's security; and (3) the accompanying effects of political practice that have undergone significant and even surprising changes. ${ }^{2}$

The securitization of the concept of migration implies, for example, its construction as a matter of security threat of great and existential significance for the Member States of the European Union and European culture as a whole. ${ }^{3}$ Therefore, "societal security" has become one of the main areas of security addressed by representatives of the Copenhagen School. Proponents of the conventional-critical approach believe, for example, that security can contribute to a regression in the debate about whether immigrants and refugees are in fact posing a threat to the state. This situation may in fact motivate groups of nationalists who explain their behavior towards migrants as an attempt to defend their own "societal security".

Barry Buzan pointed out three possible threats to the societal security of local society in a given state. ${ }^{4}$ The first of them, horizontal competition, transforms the identity of a local population through the cultural and linguistic influences of the neighboring culture. According to Buzan, another threat is vertical competition. It takes place through the inclusion of the culture of a given group in the broader definition of culture, or through the disintegration of broadly understood culture into smaller elements. Finally, the last factor threatening the identity of the society and its security is migration which changes the structure of the entire society. Immigrants form a cultural, religious, linguistic (and sometimes

of the Most Dangerous Challenges to European Security in the 21st Century), „Studia Europejskie - Studies in European Affairs", no. 4/2019, pp. 49-52.

2 P. Bourbeau, The Securitization of Migration: A Study of Movement and Order, London/New York 2011, p. 1.

3 V. Lalić, P. Ćeranić, Securitization of Migration in European Union and the Role of Private Security Firms, „Security Dialogues”, no. 1/2019, p. 48.

${ }^{4}$ B. Buzan, O. Wæver, J. de Wilde, Security: A New Framework for Analysis, Colorado/London 1998, p. 121. 
racial) minority in a given country and change its entire social structure (specifically ethnic, cultural, religious and linguistic elements of the population ${ }^{5}$ ). In cases of violation of generally accepted norms and values, the citizens of the host country may see immigrants as a threat to their own societal security, and the state may defend itself against migration by using the argument of "otherness" of immigrants.

It can be assumed, however, that in the case of Turkey, the issue of securitization of societal security is, however, of secondary importance. Refugees are perceived by the host community mainly in the context of being a threat to social security (the access to the labor market, public services - including health services, high costs of maintaining refugees) and in this particular context they consider the legitimacy of the presence of refugees in Turkey. The aim of this article is to verify the hypothesis stated above as well as to present the impact of the migration crisis and the inflow of Syrian people on the situation in Turkey. Another objective of this analysis is to answer the following questions: How has Turkey's policy towards refugees and asylum seekers from Syria changed, and how has it affected Turks' attitude towards Syrians? What consequences have the migration crisis and the increase in the number of admitted refugees caused in Turkey? How do Turks and the Turkish state jusify their approach to refugees and what do they see as the greatest threat to social security and security of the state?

Through the investigation of social reality we can refer to many methodological categories. ${ }^{6}$ In case of this analysis, it seems especially important to pay attention to the interrelationship of the studied phenomena. It is crucial to investigate the way in which the influx of immigrants to Turkey has affected the situation of the local community and its approach towards helping refugees. In this way, it may be possible to conclude whether the totality of changes and relations that have taken place in Turkey over the past years have characteristics of individual (i.e. whether the processes can be described as identical to those occurring in other countries) or particular nature (specific only in this case). To achieve this objective, it seems reasonable to use the technique of the analysis of source material and secondary analysis of quantitative and qualitative existing data. Reports from opinion polls also hold an important place in the material used for this research.

5 Y. A. Stivachtis, International Migration and the Politics of Identity and Security, „Journal of Humanities \& Social Science”, vol. 2, no. 1/2008, p. 3.

6 J. Sztumski, Wstęp do metod i technik badań spotecznych (Introduction to Methods and Techniques of Social Research), Katowice 2019, pp. 27-28. 


\section{Migration Crisis and the Increase in the Number of Refugees in Turkey}

The issue of migration and better control of the flow of refugees and asylum seekers has become the main theme in Turkey's relations with the European Union in recent years. In December 2013, both partners signed a Readmission Agreement, which entered into force on October 1, 2014. The aim of the agreement was to strengthen cooperation between the parties with a perspective of effective combating of illegal immigration. It set out procedures for establishing the identity of people residing illegally in Turkey or one of the EU countries, as well as for returns and facilitating transit. As the migration crisis intensified and Turkey was identified as a strategic partner in the attempt to overcome it, mutual cooperation in the field of migration and bilateral relations entered a new stage. This resulted in the signing of an EU-Turkey Statement of 18 March 2016, ${ }^{7}$ which was to ensure deeper relations and searching for a solution to the migration crisis through a bilateral commitment. Turkey decided to accept the rapid return of all immigrants who did not require international protection from Turkey to Greece and to take back all those irregular migrants who were detained in Turkey's territorial waters. Both sides agreed to the further strengthening of measures to combat immigrant smugglers and welcomed NATO's ${ }^{8}$ findings in the Aegean Sea.

Turkey's actions, combined with the actions of the member states, almost immediately blocked the mass flow of immigrants by the so-called Balkan Route on the territory of the European Union. The number of daily journeys dropped by $97 \%$ from 10000 in one day in October 2015 to 83 (on March, 21 2016). Also, the number of deaths in the Aegean Sea dropped significantly from 1175 in the 20 months before the declaration to $310 .{ }^{9}$ Turkey, therefore, included both the possibilities and the tools that proved necessary to overcome the crisis. At the same time, however, the number of refugees staying in Turkey increased. According to UNHCR $^{10}$ data from November 30, 2019, the country currently has the largest population of refugees and asylum seekers in the world, reaching

7 Communication from the Commission to the European Parliment, the European Council and the Council, First Report on the progress made in the implementation of the EU-Turkey Statement, COM(2016) 231 final, Brussels 20.04.2016.

${ }^{8}$ North Atlantic Treaty Organization.

9 European Commission, EU-Turkey Statement Three years on, March 2019, https://ec.europa.eu/home-affairs/sites/homeaffairs/files/what-we-do/policies/european-agenda-migration/20190318_eu-turkey-three-years-on_en.pdf (access 9.03.2020).

10 The UN Refugee Agency. 
almost 4 Million. The largest group are citizens of Syria (3.6 Million), followed by newcomers from Afghanistan (170 000), Iraq (142 000) and $\operatorname{Iran}(39000)$.

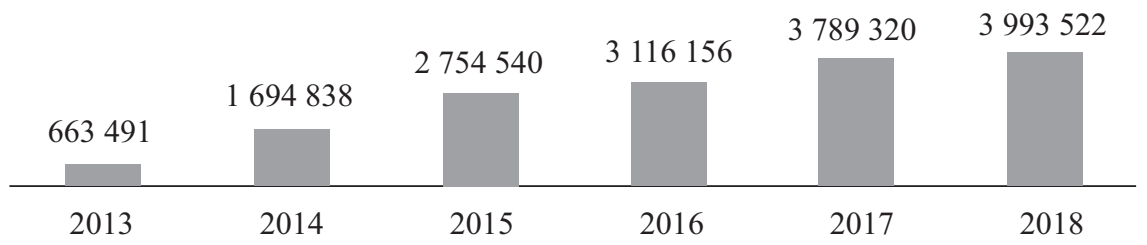

Figure 1. Number of Refugees in Turkey (2013-2018)

Source of data: UNHCR - Turkey Stats.

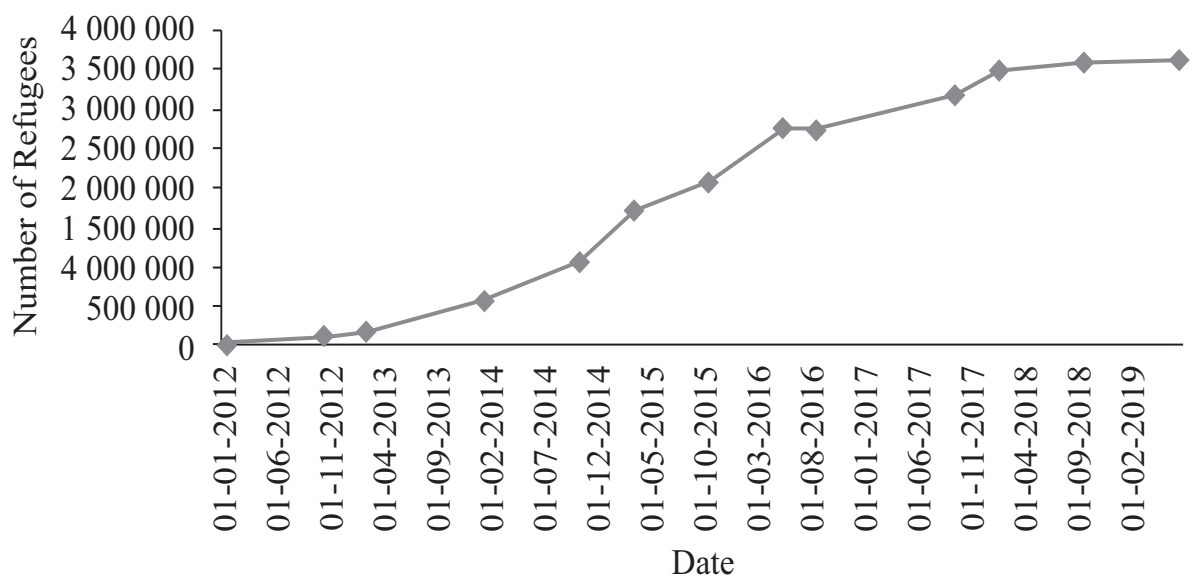

Figure 2. The Increase in the Number of Refugees in Turkey (2012-2019) Source of data: UNHCR - Turkey Stats.

\section{Turkey's Policy Towards Syrian Refugees}

In the first years of the gradual appearance of Syrian refugees on Turkish territories, the government's activities could be described as proactive. ${ }^{11}$ Individual state policy entities at the central as well as provincial level, provided both the support and numerous benefits to refugees and asylum seekers. In order to use public services such as social assistance, health

11 S. Aydın-Düzgit, F. Keyman, K. Biehl, Changing Parameters of Migration Cooperation: Beyond the EU-Turkey Deal?, Istanbul 2019, p. 5. 
care and education, newcomers from Syria were required to register. By 2013, the Turkish authorities had registered 225000 refugees so their population was not difficult to control. The government could focus on the crisis response policy, the main element of which was the creation and operation of Temporary Accommodation Camps (TACs) and taking into account primarily the housing and nutritional needs of refugees and asylum seekers. In the provinces bordering Syria, all newcomers were offered free medical care and education (in Temporary Education Centers - TEC).

In November 2014, the Syrian population in Turkey represented 2.1\% of the total population of this country. However, this percentage increased over time and reached $2.5 \%$ by September 2015. ${ }^{12}$ In turn, in ten Turkish cities near the Syrian border (the population of which is estimated at 10 million people) those numbers were much higher (as a result of the fact that there were 1.2 million refugees located in this region). Thus, in the three border regions, the Syrian refugee community constituted the highest percentage of its population in Turkey (from $8-14 \%{ }^{13}$ ). This rapid population growth left, among others, a heavy burden on health services, both in terms of human resources and logistics. Only in 2015, over half a million Syrian patients were transferred from refugee camps to public hospitals, and about 35000 Syrian children were born in them (Ministry of Health data). Hospitals in the bordering regions began to dedicate $30-40 \%$ of their capacity to help Syrian patients. This situation caused dissatisfaction of the local community and contributed to the creation of, among others, health centers exclusively for refugees (in which social workers, psychologists and translators were employed in addition to medical staff). In bordering cities, the number of doctors increased multiple times over one year (Şanlıurfa - from 156 to 380, Gaziantep from 65 to $\left.179^{14}\right)$.

Only at the beginning of 2015, the Turkish state spent about 6 billion USD on refugee assistance (at a time when external assistance amounted to 300 million USD). This sum was intended for food, various services and basic necessities such as medicines, clothing, shelter and housing. ${ }^{15}$

12 P.E. Ekmekci, Syrian Refugees, Health and Migration Legislation in Turkey, „Journal of Immigrant and Minority Health", no. 19, vol. 1434-1441/2017, p. 7.

13 Y.K. Bagir, Impact of the Syrian refugee influx on Turkish native workers: An ethnic enclave approach,"Central Bank Review", vol. 18, no. 4/2018, p. 131.

14 P.E. Ekmekci, op. cit., p. 7.

15 X.V. Del Carpio, M. Wagner, The Impact of Syrian Refugees on the Turkish Labor Market, „Policy Research Working Paper”, no. WPS7402/2015, p. 8. 
The open door policy ${ }^{16}$ and the rapid increase in the number of refugees initiated in 2014 resulted, apart from the huge costs, also in the inability to admit them all to TAC centers. Syrians began to move to other parts of Turkey. Significant clusters were formed not only near the border with Syria, but in most of the Turkish regions and cities (the highest rates, among others, in Istanbul, Izmir and Bursa). As a result of the growing challenges related to the Syrian refugee issue, government's policy has gradually moved from a phase of temporary crisis management towards a long-term integration approach. The actions were focused on taking the necessary measures to adapt migrants to the economic and social life of the country. ${ }^{17} \mathrm{At}$ a time when the population of refugees living in the TAC fell below the number of Syrians permanently residing in Turkish cities (in January 2019, there were 13 such large-scale camps accommodating a total of $143558^{18}$ ), the government provided them with help to rent accomodation, as well as the necessary resources. Unlike the EU's countries, however, Turkey has not developed a separate policy on the use of public goods for people under temporary international protection. Therefore, the policy towards refugees from Syria is based on an approach to using public services in the same way as for the citizens of the state. ${ }^{19}$

On the other hand, some Syrian families receive subsidies under Emergency Social Safety Net (ESSN) and the Conditional Cash Transfer for Education (CCTE) programs developed in Turkey's agreement with the European Union in March 2016. These programs helped refugees meet some of the social and educational needs. Those refugee families qualifying for ESSN support receive 120 TRY (around 19 euros $^{20}$ ) per person per month (as part of the transfer of funds to a special debit card $\left.^{21}\right)$. In addition, Syrian families also receive transfers paid quarterly ("top-ups") depending on the size of the family. Refugees with severe

${ }^{16}$ S. Kınıklığlu, Syrian Refugees in Turkey: Changing Attitudes and Fortunes, „SWP Comment", no. 5/2020, p. 1.

17 The Division for Sustainable Development Goals (DSDG), Turkey's 2nd VNR 2019 Sustainable Development Goals "Strong Ground towards Common Goals", p. 44, https://sustainabledevelopment.un.org/content/documents/23862Turkey_VNR_110 719.pdf (access 10.03.2020).

${ }_{18}$ The Asylum Information Database (AIDA), Housing Turkey, https://www.asylumineurope.org/reports/country/turkey/housing-1 (access 10.03.2020).

19 The Division for Sustainable Development Goals (DSDG), op. cit., p. 44.

${ }^{20}$ European Commission, Questions and answers: Support for refugees in Turkey through the Emergency Social Safety Net, https:/ec.europa.eu/commission/presscorner/detail/en/QANDA_19_6212 (access 1.06.2020).

${ }_{21}$ World Food Programme, The Emergency Social Safety Net (ESSN). Helping Refugees in Turkey, https://reliefweb.int/sites/reliefweb.int/files/resources/ WFP-0000104792.pdf (access 1.06.2020). 
disabilities can expect additional 600 TRY for special expenditures. ${ }^{22}$ The Turkish government has also made some efforts to improve the living conditions of Syrian refugees under temporary protection. These efforts included undertaking measures to provide vocational training and language courses (via Turkish employment agencies and chambers of commerce). In December 2017, work permit fee was reduced from 537 TRY (97 USD) to 200 TRY (36 USD) (increased in the meantime to 372 TRY (67 USD ${ }^{23}$ ).

The support for Syrians is, however, often insufficient. As a result, they look for jobs that can provide them with additional income (mainly in the sectors of agriculture, industry and small enterprises, ${ }^{24}$ in the textile and clothing sectors, as well as in education, construction and services ${ }^{25}$ ). It is estimated that the number of Syrians who took up employment in Turkey is between 500000 and one million, and by the end of 2018 only 65000 work permits were issued (according to the Interior Minister of Turkey ${ }^{26}$ ). Due to the fact that most refugees do not have a work permit, they participate in the Turkish labor market illegally (for example, as many as $92 \%$ of Syrians employed in the agricultural sector and $20.7 \%$ of Syrian educational workers work in the informal market).

Informal employment is primarily associated with low wages (well below the statutory minimum wage), as well as poor working conditions and exploitation, especially referring to children and women. Some Turkish employers eagerly employ refugees in their companies in order to avoid paying higher wages and social security contributions. ${ }^{27}$ As Burcu Togral Koca notes, numerous studies and analyzes show that refugees in Turkey live in uncertain situations. They are victims of human trafficking and economic exploitation, as well as forced to prostitution and begging. Over $70 \%$ of refugees live in extreme or moderate poverty. ${ }^{28}$ Some of

${ }^{22}$ Ibidem.

23 I. Leghtas, Insecure Future: Deportations and Lack of Legal Work for Refugees in Turkey, p. 11, https://www.refugeesinternational.org/reports/2019/9/18/insecure-future-deportations-and-lack-of-legal-work-for-refugees-in-turkey (access 1.06.2020).

${ }_{24}$ P.E. Ekmekci, op. cit., p. 9.

25 K. Kirişci, G. Uysal Kolasin, Syrian refugees in Turkey need better access to formal jobs, https://www.brookings.edu/blog/order-from-chaos/2019/07/18/syrian-refugeesin-turkey-need-better-access-to-formal-jobs/ (access 1.06.2020).

${ }^{26}$ Ibidem.

27 U. Farooq, N. Bulos, Anti-refugee sentiment grows in Turkey as government begins to send Syrians back, https://www.latimes.com/world-nation/story/2019-07-25/turkeyshows-signs-of-exasperation-over-refugees (access 1.06.2020).

${ }^{28}$ K. Kirişci, G. Uysal Kolasin, op. cit. 
them do not have access to apartments and therefore occupy parks and abandoned buildings. ${ }^{29}$

Over the past five years, as a result of the process of gradual ghettoisation of refugees, there has also been a nearly six-fold increase in the rate of crime committed by this community. Living apart from the Turks, Syrian refugees captured some districts of Turkish cities (including Istanbul). Although the incidents of violence were rather negligible, xenophobic monitoring $\mathrm{NGOs}^{30}$ indicate that since the beginning of the Syrian war, over 70 spontaneous hatred-promoting campaigns against Syrians have been organized in Turkey, which have received positive feedback from social media users. ${ }^{31}$

Attacks on representatives of the Syrian community began to spread beyond the Internet over time. In early July 2019, human rights organizations reported a wave of attacks on companies owned by Syrians in Istanbul. Some representatives of this community also noted that apartment owners are less willing to rent them flats. They began to blame the Turkish media for this, because they believe that refugees were portrayed in a negative light.

\section{The Impact of the Migration Crisis on the Socio-political Situation in Turkey and Turks'Approach Towards Syrian Refugees}

Initially, the Turkish society showed a high degree of tolerance for Syrian refugees and asylum seekers. It resulted, among others, from the rhetoric of the authorities [particularly strong during the office of Prime Minister Ahmet Davutoğlu (2014-2016)] and pro-government media. The admission of Syrian refugees was argued as an expression of a kind of "neo-ottoman paternalism" towards the Arab population and Turkey's humanitarian duty towards fellow believers. ${ }^{32}$ The image of the state was contested by the attitude of the West, but at the same time, by exposing its moral advantage, it positively influenced Turkey's image in the Muslim world.

${ }^{29}$ B.T. Koca, Syrian refugees in Turkey: from “guests” to “enemies”?, „New Perspectives on Turkey", no. 54/2016, p. 66.

30 Non-government Organizations.

31 M. Chudziak, M. Marszewski, Ktopotliwi goście. Tureckie plany rozwiazania kwestii uchodźców syryjskich (Troublesome guests. Turkish plans to resolve the issue of Syrian refugees), „Komentarze OSW”, no. 310/2019, pp. 2-3.

32 Ibidem, p. 3. 
The Turkish government's decision to gradually close refugee camps (only in 2018 six camps were closed down ${ }^{33}$ ) resulted also in a decrease in the population living in the camps. At the same time, consequences of this decision increased the number of refugees moving to the largest cities in Turkey. More than half of the 3.6 million Syrians in January 2019 were registered in 4 out of the 81 Turkish provinces (Istanbul, Şanliurfa, Hatay and Gaziantep ${ }^{34}$ ). Only in Istanbul, the number of refugees reached 1 million, only half of whom $\left(548000^{35}\right)$ are officially registered.$^{36} \mathrm{~A}$ significant proportion of refugees also continue to stay in the cities near the border Gaziantep (443 000), Sanliurfa (431 000) and Hatay (430 000). ${ }^{37}$ The beneficiaries of temporary protection correspond to $21.4 \%$ of the population in Gaziantep, $22.2 \%$ in Şanlıurfa, $27.3 \%$ in Hatay and $82.2 \%$ in Kilis. ${ }^{38}$ According to Suat Kınıklığlu, this situation changed the perception of Syrians to "urban refugees", because as many as $98 \%$ of them began to reside in cities $^{39}$ (this is not confirmed by FAO's data from December 2017; according to FAO, 93.5\% refugees from Syria reside amongst host communities in rural, semi-rural and urban $\left.\operatorname{areas}^{40}\right)$. As David Lepeska notes, Syrians have become an integral part of Istanbul and other Turkish cities, and in accordance with the Turkish Ministry of Commerce, they contributed, among others, to the creation of more than 15000 new companies in the country employing nearly 100000 people (including Turks ${ }^{41}$ ). The issue of their return to their homeland began to be addressed more and more often by both individual officials and members of Turkish society.

The attitude towards the Syrian brothers has also changed over time. This situation has been affected by economic problems that began to appear in Turkey (the value of the Turkish currency dropped sharply as both inflation and unemployment increased), as well as social tensions, especially among the working class competing with refugees for modest

${ }^{33}$ The Asylum Information Database (AIDA), op. cit.

${ }^{34}$ Ibidem.

35 This corresponds to $3.7 \%$ of Istanbul's population.

${ }^{36}$ M. Chudziak, M. Marszewski, op. cit, s. 3.

37 O. Karaspan, Turkey's Syrian Refugess - the Welcome Hades, https://www.brookings.edu/blog/future-development/2019/11/25/turkeys-syrian-refugees-the-welcomefades/ (access 10.03.2020).

38 The Asylum Information Database (AIDA), op. cit.

39 S. Kınıklığlu, op. cit., p. 2.

40 Food and Agriculture Organization of the United Nations, TURKEY Syrian Refugee Resilience Plan 2018-2019,pp. 2-3, http://www.fao.org/fileadmin/user_upload/ emergencies/docs/Fao-syrian-refugee-plan2018-19.pdf (access 10.03.2020).

${ }_{41}$ D. Lepeska, How Imamoğlu betrayed Istanbul, https://ahvalnews.com/syrianrefugees-turkey/how-imamoglu-betrayed-istanbul (access 10.03.2020). 
housing and jobs. ${ }^{42}$ Although most of the Syrians took the worst paid jobs, in the face of the economic crisis, it was perceived by some members of the local community as a reason for not having their own employment.

Turks' concerns are also confirmed by studies of Ximen Del Carpio and Mathis Wagner (2015), Oğuz Esen and Ayla Oğuş Binatlı (2017) and Mehmet Duruel $\left(2017^{43}\right)$ regarding the impact of the increase in the number of refugees in Turkey on employment in the informal labor market. Analyzes showed that the illegal employment of refugees causes reduction of wages in the informal sector in Southeastern Anatolia and also displaces Turkish workers from it. Similarly, it could be seen in the case of Istanbul, which became the main direction of migration of Syrians. It is estimated that young Syrian refugees earn on average $27 \%$ less than their Turkish counterparts. ${ }^{44}$

The debate on the economic consequences of receiving Syrian refugees intensified during the campaign before the parliamentary and presidential elections in 2018..$^{45}$ The opposition Republican People's Party (CHP) has repeatedly called for the need to resettle Syrians to their homeland and discontinue their admission by Turkey. This opinion was expressed, among others, by one of the Turkish presidential candidates Muharrem Ince (CHP), who primarily tried to respond to Turks' concerns over the presence of Syrian refugees. During the election campaign, $M$. Ince even made a promise to resettle Syrians to their own country. ${ }^{46}$ In one of the interviews before the presidential election, he commented on the decision made by the government, which allowed 70000 Syrians to return to their homeland for the upcoming Muslim festival Eid al-Fitr and then reenter Turkey as a place of protection and permanent residence. According to Ince, "holiday trips to Syria" served as a confirmation of the fact that refugees were safe there and could return home. ${ }^{47}$ Although his comments

${ }^{42}$ Z. Weise, Syrian refugees in Turkey face calls to return as public mood changes, https://www.thenewhumanitarian.org/feature/2018/03/27/syrian-refugees-turkeyface-calls-return-public-mood-changes (access 10.03.2020).

${ }^{43}$ O. Esen, A.O. Binatl, The Impact of Syrian Refugees on the Turkish Economy: Regional Labour Market Effects, „Social Sciences”, no. 6/2017, pp. 9-10.

${ }^{44}$ K. Kirişci, G. Uysal Kolasin, op. cit.

45 R. Mohydin, Media Coverage, Perception and Evidence: The Economic Impact of Syrian Refugees in Turkey, p. 7, https://researchcentre.trtworld.com/images/files/reports/EconomicImpactSyrianRefugees.pdf (access 1.06.2020).

46 JUSOOR for Studies, The Syrian Case In The Turkish Elections, p. 8, https:// www.jusoor.co/content_images/users/1/contents/687.pdf (access 1.06.2020).

47 M. Cetingulec, Fate of Syrian refugees hot election topic in Turkey, https://www. al-monitor.com/pulse/originals/2018/06/turkey-elections-fate-syrian-refugees-hottopic.html (access 1.06.2020). 
were subject to criticism from various environments, many users of social networks agreed with this position. ${ }^{48}$

During the 2018 presidential campaign, the incumbent President Recep Tayyip Erdoğan also promised to send refugees to their homeland, but he expressed it in a far less resolute manner. Instead, he convinced voters that the naturalization of Syrians would help them in their effort to support themselves and thus remove the burden of their maintenance from the Turkish state.

The issue of Syrian citizenship was first raised by R.T. Erdoğan as early as 2016. On 2nd July 2016 in Kilis, he stated that: "Turkey is a homeland for Syrians coming from Syria [...] and if some of them wish to become Turkish citizens, we will grant our Syrian brothers citizenship, and we will be able to pursue the case through a bureau we have established". ${ }^{49}$ These words, which were said in a Turkish city where the number of Syrians is higher than the number of Turks, became a subject of heated public debate. Twitter users even started to use the hashtag \#UlkemdeSuriyeliIstemiyorum ("I don't want Syrians in my country" which emphasised their opposition to Syrian refugees. Most likely, as a result of the opposition of a significant part of Turkish society to the admission of Syrians and the possibility of granting them citizenship, subsequent statements by the president were no longer as open and universal. Instead, he repeatedly confirmed the possibility of granting citizenship only to specialists, businessmen and orphans.

The increasingly less favorable attitude of Turkish society towards the refugee and asylum seeker community ${ }^{51}$ began to cause greater problems for the authorities. This was demonstrated by the results of the elections for the Mayor of Istanbul in 2019, in which the candidate from the ruling party in Turkey (Justice and Development Party - AKP), Binali Yildırım lost to the opposition candidate Ekrem Imamoglu (CHP). The importance of this failure can be proved by the words of the president Erdoğan himself, who once said "whoever wins Istanbul, wins Turkey". ${ }^{52}$ Although the results of local government elections usually have a limited influence on the political directions of the country, their symbolism in

48 Ibidem.

49 Enab Baladi, What's New in Turkey with the Naturalization of the Syrians there?, https://english.enabbaladi.net/archives/2017/08/whats-new-turkey-naturalizationsyrians/\#ixzz6O7VKDy3n (access 1.06.2020).

50 S. Girit, Turks hit back at Erdogan plan to give Syrians citizenship, https://www. bbc.com/news/world-europe-36704791 (access 1.06.2020).

51 D. Lepeska, op. cit.

52 M. Lowen, Erdogan's party suffers blow after Istanbul re-run poll defekt, https:// www.bbc.com/news/world-europe-48739256 (access 10.03.2020). 
the case of Turkey is indisputable. As the history of this state has shown, the results of local government elections turned out to be the beginning of a new stage in the state policy. ${ }^{53}$ It primarily refers to the elections in 1994 when R. Erdoğan took the office of Mayor of Istanbul, then became the prime minister and a few years later the president. Together with his AKP party he has been continuously exercising power in the state since 2002 . Shortly after the victory in June 2019, E. Imamoğlu himself assessed that the issue of refugees is a serious trauma for Turkey. He also linked the stay of refugees with economic problems of the state saying that: "There are many Syrians who work unregistered. [Turkey] must protect the interests of [its] people. [Syrians] can't recklessly change the color of Istanbul". ${ }^{54}$

E. Imamoğlu won the election, among others, in the conservative district of Fatih ${ }^{55}$ where the AKP's results in the last four elections did not fall below 51\%. Part of the party's electorate, which this time showed its support to the opposition candidate, cited the failure of finalizing the return of the Syrians to their homeland by the ruling party as one of the two main reasons for this decision. ${ }^{56}$ Turkish researchers Ali Fisunoğlu and Deniz Sert showed in their analysis that refugees had a negative (but nonetheless insignificant) impact on the support for the AKP in the districts with a significant concentration of refugees. ${ }^{57}$ Therefore, it can be assumed that in the face of the economic crisis, the funds directed by the AKP to provide for Syrians, caused gradual dissatisfaction among various social groups and were undoubtedly of utmost significance for the results of local elections.

This can also be seen in the results of public opinion polls conducted since the beginning of the refugee crisis. For example, data from 2016 showed that AKP voters assessed the impact of Syrian refugees on the economic opportunities of the Turkish population and the economy of the country less negatively and were more favorable towards government services for the refugees than voters of other political parties. Over half of

53 G. Dalay, Istanbul Election: Remaking of Turkey's New Political Landscape?, „SWP Comment”, no. 31/2019, p. 3.

${ }^{54}$ D. Lepeska, op. cit.

55 Yeni Şafak, 23 Fune 2019 Ístanbul - Fatih Election Results, https:/www.yenisafak.com/en/23-haziran-istanbul-secimi/istanbul-fatih-ilcesi-secim-sonuclari (access 10.03.2020).

56 BBC News, Seçim sonuçlarn: Istanbul Fatih'te AKP seçmeni İmamoğlu'nun zaferi için ne diyor? (Results of the election: What does AKP voter say about Imamoğlu's victory in Fatih?), https://www.bbc.com/turkce/haberler-dunya-48742269 (access 10.03.2020).

57 B. Esen, S. Gumuscu, Killing Competitive Authoritarianism Softly: The 2019 Local Elections in Turkey, „South European Society and Politics”, vol. 24, no. 3/2019, p. 322. 
the respondents also perceived the stay of the Syrians as temporary and hoped that after resolving the conflict, refugees would return to their country. ${ }^{58}$ Optimism in this matter, however, gradually faded. In the Kadir Has Universiy survey from 2019 , over $70 \%$ of respondents (70,9\%) claimed to have stopped believing in the return of Syrian refugees to Syria at all..$^{59}$

Numerous public opinion polls also show a gradual decline in public support for the very idea of accepting refugees. Research by İstanbul Bilgi University Center for Migration Research (CMR), published in 2018, showed, among others, that a significant proportion of Turks is in favor of sending refugees to their home country, and that this solution is supported by voters from all the leading political parties. In 2018, as many as $83.2 \%$ of respondents supporting the AKP were in favor of sending refugees back (also among voters of other political parties this percentage is high and oscillates between $75.9 \%$ and $94.9 \%) .{ }^{60}$

Analyzes conducted by Turkish researchers show that the mass influx of Syrians into Turkey caused only a slight decrease in support for the AKP and had a statistically insignificant impact on the election results. ${ }^{61}$ In the case of the 2019 March and June elections, the results gave a clear signal that a part of the previously loyal AKP electorate, for some reason did not support the party this time. ${ }^{62}$ Although the refugee case is probably not the main reason for the electoral failure, along with the economic crisis of the state and security issues, it can be considered at least as an indirect factor leading to the fall in AKP's support in the recent elections in Istanbul or Ankara.

The stay of Syrians in Turkey is not welcomed today by the large majority of Turks. According to research by scientists from Kadir Has University, most citizens of this country do not express satisfaction with the stay of Syrians. Answering a question: "To what extent are you content

58 O. Altindag, N. Kaushal, Do Refugees Impact Voting Behavior in the Host Country? Evidence from Syrian Refugee Inflows in Turkey, „Discussion Paper Series”, no. 10849/2017, p. 14.

59 Kadir Has Üniversitesi, \#TE2019. Türkiye Eğilimleri - 201915 Ocak 2020 (TE2019. Turkey Trends - 2019 Fanuary 15, 2020), p. 82, https://www.khas.edu.tr/sites/ khas.edu.tr/files/inline-files/TE2019 TUR_BASIN_15.01.20\%20WEB\%20versiyon\%20powerpoint_0.pdf (access 10.03.2020).

60 Istanbul Bilgi University Center for Migration Research, Dimensions of Polarization in Turkey. February 6th, 2018, Ankara, p. 63, https://goc.bilgi.edu.tr/media/ uploads/2018/02/06/dimensions-of-polarizationppt_Tz7XeBg.pdf (access 10.03.2020).

${ }^{61}$ O. Altindag, N. Kaushal, op. cit.

${ }^{62}$ H. Duran, What do Statistics Tell us about the Istanbul Elections?, https://thenewturkey.org/what-do-statistics-tell-us-about-the-istanbul-elections (access 10.03.2020). 
with the presence of Syrian refugees in Turkey?", the surveyed Turks overwhelmingly replied „I am discontent” (in $2019-67.7 \%$, in $2018-$ $61 \%$, in $2017-54.5 \%)$. Refering to another question: "What kind of policy should Turkey adopt towards refugees?", most of the respondents replied "Should stop accepting refugees" (in $2019-57.6 \%$, in $2018-46.3 \%$, in $\left.2017-46.4 \%^{63}\right)$. Among the most significant reasons for dissatisfaction, the respondents cited Syrians' tendency to commit crimes, the lack of peace of the local community, growing unemployment caused by illegal labor, the destruction of national identity, the use of the state's possibilities granting privileges to Syrian refugees and, finally, cultural differences. ${ }^{64}$ Syrian refugees are therefore perceived by the Turkish people mainly as a community that disturbs order, steal jobs and is a threat to national identity.

It is very likely that the attitude of Turkish people towards Syrians and the results of the 2019 local elections influenced the announcement of a policy which further specified the conditions of Syrian refugees' stay in Turkey by the AKP government. Since the beginning of the migration crisis, Syrian refugees did not have free access to the labor market and their possibility of moving within Turkey was limited. In order to leave the province in which the refugee was registered, he needed a written consent. ${ }^{65}$ Initially, this was done to a limited extent. However, shortly after the local elections (July 2019), the Turkish authorities announced that Syrians who were in Istanbul and were registered elsewhere had to return or leave the city until 20th August $2019 .{ }^{66}$ As a result, Syrians not registered in any of the Turkish provinces could be deported back to Syria (where Turkey had created enclaves for the returnees ${ }^{67}$ ). According to researchers from Refugee International, first information about the deportations of Syrian men began to appear as early as in July 2019. This was followed by an intensive investigation of identity documents, including districts with large concentrations of Syrian population. Turkish authorities reported that the action was directed against 12000 illegal migrants, primarily from Afghanistan, Pakistan and other third countries. In fact, it has been documented that hundreds of Syrians were deported to their country during this period. Those who could not show

${ }^{63}$ Center for Turkish Studies of Kadir Has University, \#TDP2019. Public Perceptions on Turkish Foreign Policy, 4 July 2019, p. 84, https://www.khas.edu.tr/sites/khas. edu.tr/files/inline-files/TDP-2019_BASINENG_FINAL.PDF (access 10.03.2020).

${ }^{64}$ Kadir Has Üniversitesi, op. cit., p. 81.

65 I. Leghtas, op. cit., p. 7.

${ }_{66}$ Returns were extended to October 30, 2019.

67 U. Farooq, N. Bulos, op. cit. 
their registration document were urged to sign voluntary repatriation forms and return to Syria. ${ }^{68}$

As Suat Kınıklığlu notes, although the AKP is aware of the fact that the probability of Syrian refugees returning to their country is small, the loss of voters in local elections has forced the party to show the public that the government has full control over the situation. ${ }^{69}$ Therefore, the Operation Source of Peace, launched in October 2019, justified the need to resettle refugees to northern Syria and increased Turkish public support for the operation itself. In the months preceding the intervention, Turkey convinced international community and its own society of its humanitarian character and the need to build a buffer zone to enable the resettlement of some Syrian refugees. However, according to the European Union, the operation was of a military nature and is the third, after the "Euphrates Shield" (2016-2017) and "Olive Branch" (2018) armed intervention in Syria. ${ }^{70}$

The Turkish people themselves express a slightly different attitude to the intervention. Answering the question: "Do you support the peace operation that Turkey has begun in Syria?", as many as $75.6 \%$ of respondents answered affirmatively (only $24.4 \%$ had a different opinion ${ }^{71}$ ). In turn, refering to the question: "What do you think is the main reason for starting the operation?" the second most popular answer was the need to create a safety zone and place refugees there, which was cited by a quarter of the respondents (25.6\%) (more respondents cited the need to ensure security at the border as the main reason $-42.6 \%$ ). Therefore, the results of this research clearly indicate that, in the opinion of the Turks, Operation Source of Peace in Syria was related to the possibility of resettling Syrians there.

\section{Conclusions}

Issues concerning Syrian migration to Turkey can be considered in two differnet contexts. First of all, it can be assumed that Syrians are a community from the same (Muslim) civilization circle that finds its place in Turkey without much social conflict with the local population. It

${ }^{68}$ I. Leghtas, op. cit., p. 10.

${ }^{69}$ S. Kınıklığlu, op. cit., p. 2.

${ }^{70}$ European Parliament, Turkey's military operation in Syria and its impact on relations with the EU (Brifing), p. 1, https://www.europarl.europa.eu/EPRS/EPRS-Briefing-642284-Turkeys-military-operation-Syria-FINAL.pdf (access 10.03.2020), p. 1.

71 Areda, Barıs Pınar Operasyonu Algı Araştırması Ekim 2019 (Operation Source of Peace's Perception Survey October 2019), p. 6, https:/www.areda.com/wp-content/ uploads/2019/10/Barış-Pınar1-Operasyonu-Basın-Bülteni.pdf (access 10.03.2020). 
seems, however, that such a way of thinking is justified only in places where clusters of „foreign" Syrian population are smaller and where their impact on the life of the local community is very small. Second of all, considering the processes taking place in Turkey, it seems more reasonable to adopt another way of looking at consequences of migrations. This way should refer to changes that have taken place in other European countries.

The number of Syrian migrants accounts for a significant proportion of the population in some Turkish cities. Their share in the labor market, mainly informal, is noticeable. This situation is primarily associated with low-paid jobs, poor working conditions and exploitation. Some Syrians are not insured and their living conditions are very bad. Nevertheless, competition in the labor market in the form of cheap Syrian labor is seen by unemployed Turks as an obstacle for finding their own employment.

Along with the increase in the number of refugees in Turkey, the state policy towards them has changed. Turkey, which initially prepared TAC Temporary Accommodation Camps for Syrians, began to focus on providing them with access to public goods (such as health services) and basic needs. However, high costs of maintaining refugees in the context of the economic crisis have not been positively assessed by the local community, for which the Syrians, apart from "taking jobs" are also a serious burden on the state budget. Syrian people, especially in cities, undergo a ghettoization process and become groups which are clearly separate from the local community. The dislike of the Syrians was mainly reflected in social media, where numerous actions were manifested by the demonstration a negative attitude towards the presence of refugees in Turkey.

The issue of refugees is one of the factors that have had a negative impact on the perception of government policies and the AKP election results in recent local government elections. Before the elections, some politicians called for the need to send Syrians back to their homeland. After the defeat in Istanbul and Ankara in 2019, the AKP government took measures to specify the policy towards Syrian refugees. A military operation in Syria, justified by the need for creation of a safety zone in which refugees could be located, was started. Authorities also began controlling whereabouts of Syrians and, as reported by human rights organizations, started to send them back to their homeland. 


\section{References}

Altindag O., Kaushal N., Do Refugees Impact Voting Behavior in the Host Country? Evidence from Syrian Refugee Inflows in Turkey, „Discussion Paper Series", no. 10849/2017.

Areda, Barış Pınarı Operasyonu Algı Araştırması Ekim 2019 (Operation Source of Peace's Perception Survey October 2019), https://www.areda.com/ wp-content/uploads/2019/10/Barış-Pınarı-Operasyonu-Basın-Bülteni. pdf (access 10.03.2020).

Aydın-Düzgit S., Keyman S., Biehl K., Changing Parameters of Migration Cooperation: Beyond the EU-Turkey Deal?, Istanbul Policy Center, Istanbul 2019.

Bagir Y.K., Impact of the Syrian refugee influx on Turkish native workers: An ethnic enclave approach, "Central Bank Review", vol. 18, no. 4/2018, DOI: https://doi.org/10.1016/j.cbrev.2018.11.001.

BBC News, Seçim sonuçlart: Istanbul Fatih'te AKP seçmeni Imamoğlu'nun zaferi için ne diyor? (Results of the election: What does AKP voter say about Imamoğlu's victory in Fatih?), https://www.bbc.com/turkce/haberlerdunya-48742269 (access 10.03.2020).

Bourbeau P., The Securitization of Migration A study of movement and order, Routledge, London/New York 2011.

Buzan B., Wæver O., de Wilde J., Security: A New Framework for Analysis, Lynne Rienner Publishers Inc., Colorado/London 1998.

Center for Turkish Studies of Kadir Has University, \#TDP2019. Public Perceptions on Turkish Foreign Policy, 4 July 2019, https://www.khas.edu. tr/sites/khas.edu.tr/files/inline-files/TDP-2019_BASINENG_FINAL. PDF (access 10.03.2020).

Cetingulec M., Fate of Syrian refugees hot election topic in Turkey, https:// www.al-monitor.com/pulse/originals/2018/06/turkey-elections-fatesyrian-refugees-hot-topic.html (access 1.06.2020).

Chudziak M., Marszewski M., Ktopotliwi goście. Tureckie plany rozwiązania kwestii uchodźców syryjskich (Troublesome guests. Turkish plans to resolve the issue of Syrian refugees), „Komentarze OSW”, no. 310/2019.

Communication from the Commission to the European Parliment, the European Council and the Council, First Report on the progress made in the implementation of the EU-Turkey Statement, $\operatorname{COM(2016)} 231$ final, Brussels 20.04.2016.

Dalay G., Istanbul Election: Remaking of Turkey's New Political Landscape?, „SWP Comment”, no. 31/2019.

Del Carpio X.V., Wagner M., The Impact of Syrian Refugees on the Turkish Labor Market, „Policy Research Working Paper”, no. WPS7402/2015. 
Duran H., What do Statistics Tell us about the Istanbul Elections?, https://thenewturkey.org/what-do-statistics-tell-us-about-the-istanbul-elections (access 10.03.2020).

Ekmekci P.E., Syrian Refugees, Health and Migration Legislation in Turkey, "Journal Immigrant Minority Health", vol. 19, no. 1434-1441/2017.

Enab Baladi, What's New in Turkey with the Naturalization of the Syrians there?, https://english.enabbaladi.net/archives/2017/08/whats-new-turkey -naturalization-syrians/\#ixzz6O7VKDy3n (access 1.06.2020).

Esen B., Gumuscu S., Killing Competitive Authoritarianism Softly: The 2019 Local Elections in Turkey, "South European Society and Politics”, vol. 24, no. 3/2019, DOI: https://doi.org/10.1080/13608746.20 19.1691318.

Esen O., Binatli A.O., The Impact of Syrian Refugees on the Turkish Economy: Regional Labour Market Effects, „Social Sciences”, no. 6/2017.

European Commission, EU-Turkey Statement Three years on, March 2019, https://ec.europa.eu/home-affairs/sites/homeaffairs/files/whatwe-do/policies/european-agenda-migration/20190318_eu-turkey-three -years-on_en.pdf (access 9.03.2020).

European Parliament, Turkey's military operation in Syria and its impact on relations with the EU (Brifing), https://www.europarl.europa. eu/EPRS/EPRS-Briefing-642284-Turkeys-military-operation-SyriaFINAL.pdf (access 10.03.2020).

Farooq U., Bulos N., Anti-refugee sentiment grows in Turkey as government begins to send Syrians back, https://www.latimes.com/world-nation/ story/2019-07-25/turkey-shows-signs-of-exasperation-over-refugees (access 1.06.2020).

Food and Agriculture Organization of the United Nations, TURKEY Syrian Refugee Resilience Plan 2018-2019, http://www.fao.org/fileadmin/ user_upload/emergencies/docs/Fao-syrian-refugee-plan2018-19.pdf (access 10.03.2020).

Girit S., Turks hit back at Erdogan plan to give Syrians citizenship, https:// www.bbc.com/news/world-europe-36704791 (access 1.06.2020).

İstanbul Bilgi University Center for Migration Research, Dimensions of Polarization in Turkey. February 6th, 2018, Ankara, https:/goc.bilgi.edu.tr/ media/uploads/2018/02/06/dimensions-of-polarizationppt_Tz7XeBg. pdf (access 10.03.2020).

Kadir Has Üniversitesi, \#TE2019. Türkiye Ë̆ilimleri - 201915 Ocak 2020 (TE2019. Turkey Trends - 2019 fanuary 15, 2020), https://www.khas.edu.tr/ sites/khas.edu.tr/files/inline-files/TE2019_TUR_BASIN_15.01.20\%20 WEB\%20versiyon\%20powerpoint_0.pdf (access 10.03.2020). 
Karaspan O., Turkey's Syrian Refugess - the Welcome Hades, https://www. brookings.edu/blog/future-development/2019/11/25/turkeys-syrianrefugees-the-welcome-fades/ (access 10.03.2020).

Kirişci K., Uysal Kolasin G., Syrian refugees in Turkey need better access to formaljobs,https://www.brookings.edu/blog/order-from-chaos/2019/07/18/ syrian-refugees-in-turkey-need-better-access-to-formal-jobs/ (access 1.06.2020).

Kınıklığlu S., Syrian Refugees in Turkey: Changing Attitudes and Fortunes, „SWP Comment”, no. 5/2020.

Koca B.T., Syrian refugees in Turkey: from "guests” to “enemies”?, „New Perspectives on Turkey", no. 54/2016.

Lalić V., Ćeranić P., Securitization of Migration in European Union and the Role of Private Security Firms, „Security Dialogues”, no. 1/2019.

Leghtas I., Insecure Future: Deportations and Lack of Legal Work for Refugees in Turkey, https://www.refugeesinternational.org/reports/2019/9/18/ insecure-future-deportations-and-lack-of-legal-work-for-refugees-inturkey (access 1.06.2020).

Lepeska D., How Imamoğlu betrayed Istanbul, https://ahvalnews.com/syrian -refugees-turkey/how-imamoglu-betrayed-istanbul (access 10.03.2020).

Llanos-Antczak A., Problemy spoteczno-ekonomiczne jako jedne z najgroźniejszych wyzwań dla bezpieczeństwa europejskiego w XXI wieku (SocioEconomic Problems as One of the Most Dangerous Challenges to European Security in the 21st Century), "Studia Europejskie - Studies in European Affairs", no. 4/2019.

Lowen M., Erdogan's party suffers blow after Istanbul re-run poll defekt, https://www.bbc.com/news/world-europe-48739256 (access 10.03.2020).

Mohydin R., Media Coverage, Perception and Evidence: The Economic Impact of Syrian Refugees in Turkey, https://researchcentre.trtworld.com/images/ files/reports/EconomicImpactSyrianRefugees.pdf (access 1.06.2020).

Stivachtis Y.A., International Migration and the Politics of Identity and Security, „Journal of Humanities \& Social Science”, vol. 2, no. 1/2008.

Sztumski J., Wstęp do metod $i$ technik badan spotecznych (Introduction to Methods and Techniques of Social Research), Śląsk Wydawnictwo Naukowe, Katowice 2019.

The Asylum Information Database (AIDA), Housing Turkey, https:// www.asylumineurope.org/reports/country/turkey/housing-1 (access 10.03.2020).

The Division for Sustainable Development Goals (DSDG), Turkey's 2nd VNR 2019 Sustainable Development Goals "Strong Ground towards Common Goals", https://sustainabledevelopment.un.org/content/ documents/23862Turkey_VNR_110719.pdf (access 10.03.2020). 
UNHCR, Turkey, https://data2.unhcr.org/en/situations/syria/location/113 (access 10.03.2020).

UNHCR, Turkey Fact Sheet August 2018, https://reliefweb.int/sites/reliefweb.int/files/resources/01.-UNHCR-Turkey-Fact-Sheet-August-2018. pdf (access 10.03.2020).

UNHCR, Turkey Stats, https://www.unhcr.org/tr/en/unhcr-turkey-stats (access 10.03.2020).

UNHCR, 2015 Year-End report, http://reporting.unhcr.org/sites/default/ files/pdfsummaries/GR2015-Turkey-eng.pdf (access 10.03.2020).

Wæver O., Securitization and Desecuritization, in: On Security, ed. R.D. Lipschutz, Columbia University Press, New York 1998.

Weise Z., Syrian refugees in Turkey face calls to return as public mood changes, https://www.thenewhumanitarian.org/feature/2018/03/27/syrian -refugees-turkey-face-calls-return-public-mood-changes (access 10.03.2020).

World Food Programme, The Emergency Social Safety Net (ESSN). Helping Refugees in Turkey, https://reliefweb.int/sites/reliefweb.int/files/resources/WFP-0000104792.pdf (access 1.06.2020).

Yeni Şafak, 23 fune 2019 Istanbul - Fatih Election Results, https://www.yenisafak.com/en/23-haziran-istanbul-secimi/istanbul-fatih-ilcesi-secim -sonuclari (access 10.03.2020). 